\title{
Microalgal biomass in the St Lucia Estuary during the 2004 to 2007 drought period
}

\author{
Renzo Perissinotto ${ }^{1, *}$, Deena Pillay ${ }^{1,2}$, Guy Bate ${ }^{1,3}$ \\ ${ }^{1}$ School of Biological \& Conservation Sciences, University of KwaZulu-Natal, Westville Campus, X54001, Durban 4000, \\ South Africa \\ ${ }^{2}$ Marine Research Institute, Department of Zoology, University of Cape Town, Private Bag X3, Rondebosch 7701, Cape Town, \\ South Africa \\ ${ }^{3}$ Botany Department, Nelson Mandela Metropolitan University, PO Box 77000, Port Elizabeth 6031, South Africa
}

\begin{abstract}
Phytoplankton and microphytobenthic biomass were investigated over a 4 yr period in the drought-stricken St Lucia Estuary, KwaZulu-Natal, South Africa. This is the largest estuarine lake in Africa and part of the iSimangaliso Wetlands Park, South Africa's first World Heritage Site and a Ramsar Wetland of International Importance. The present study aimed at identifying the factors controlling the extreme variability in its ecological functioning. Water-column chlorophyll a (chl a) concentrations averaged $( \pm \mathrm{SD}) 32.3 \pm 53.4 \mathrm{mg} \mathrm{m}^{-3}$, with the highest value reaching $413 \mathrm{mg} \mathrm{m}^{-3}$. Within the sediment, average $( \pm \mathrm{SD}) \mathrm{chl}$ a concentration was $201 \pm 377 \mathrm{mg} \mathrm{m}^{-2}$, with a maximum of $2576 \mathrm{mg}$ $\mathrm{m}^{-2}$. Both are among the highest values so far reported in the literature for any estuarine ecosystem and by far the highest values reported for any South African estuary. Areal phytoplankton biomass was highest in the Mouth and Narrows region, declining in the South and North lakes, while microphytobenthos showed the reverse trend. Ordinations and cluster analysis revealed that phytoplankton biomass differed between the southern and northern halves of the system, while differences in microphytobenthic biomass were found between the Narrows and the rest of the system. Dissolved inorganic nitrogen to phosphorus ratios were greater and lower than the Redfield optimum (16) $60 \%$ and $27 \%$ of the time, respectively, indicating that microalgal production may be limited by availability of either $\mathrm{P}$ or $\mathrm{N}$ for part of the year, with a peak in growth during summer. Water level and mouth state are key factors controlling microalgal biomass within the estuary. During the closed phase, the shallow waters and vast surface area of the lakes region led to the development of hypersaline conditions and temperatures occasionally approaching $50^{\circ} \mathrm{C}$. The negative effects of such extreme conditions on grazers, as well as negative correlations between grazer densities and microalgal biomass, have been documented in previous work on the system. This would suggest that the interaction between the physical environment and grazers may be important in regulating microalgal biomass in the estuary.
\end{abstract}

KEY WORDS: Phytoplankton · Microphytobenthos $\cdot$ Chlorophyll a $\cdot$ St Lucia Estuary $\cdot$ Hypersalinity · iSimangaliso Wetlands Park · World Heritage Site

\section{INTRODUCTION}

Shallow lakes around the world have recently received substantial research attention, in response to anthropogenic impacts on their structure and functioning (e.g. Scheffer 2004, Crossland et al. 2005). Often, in freshwater lakes, such impacts have led to a shift from a clear-water, macrophyte-dominated to a turbid microalga-dominated state (Mitchell 1989, Moss 1994, van der Berg et al. 1998). Estuarine lakes are more complex than their freshwater counterparts, in that they experience regular tidal action as well as the large-scale variability associated with climatic cycles in the ocean and on land. Superimposed upon these processes are the same anthropogenic manipulations that inland lakes experience. In large regions of the 
world, the variability in the dynamics of estuarine lakes also includes regular changes between open (i.e. communicating with the ocean) and closed (i.e. completely isolated from the ocean) mouth states (Whitfield 1998, Roy et al. 2001). These hydrological shifts have been shown to cause large temporal and spatial variations in microalgal composition, biomass and production (Bonilla et al. 2005, Gobler et al. 2005, Anandraj et al. 2008).

Estuarine lakes play a major role as nursery areas for the ontogenetic development and seasonal migration of a number of fish and invertebrate species of particular commercial and conservation value (Whitfield 1998, Perissinotto et al. 2003), and the St Lucia Estuary is no exception (Wallace \& van der Elst 1975, Begg 1978, Benfield et al. 1989). The system has also supported a commercial prawn fishery since the 1950 s, as well as other recreational and subsistence fisheries, and is recognised throughout southern Africa for its excellent fishing and rich bird life and as a national and regional asset (Begg 1978). The uniqueness of this system has been widely recognised, especially with its incorporation into South Africa's first World Heritage Site (Greater St Lucia Wetlands Park, recently renamed iSimangaliso Wetlands Park) in 1999. It is the largest estuarine lake in Africa, with a surface area of $350 \mathrm{~km}^{2}$ and a shoreline of $>400 \mathrm{~km}$ in length (Day 1981, Fielding et al. 1991) and was proclaimed a Ramsar Wetland in 1991.

The St Lucia system has historically been typified by episodic droughts and flooding events, resulting in alternating periods of very low salinity and hypersaline conditions, which inflict a considerable stress on the resident organisms (Taylor 2006). The system is currently experiencing one of the most severe droughts in recorded history, and its mouth has largely been closed off from the Indian Ocean since June 2002 (Cyrus \& Vivier 2006). It opened to the ocean briefly via the adjacent Mfolozi River during a flood in January 2004 (Cyrus \& Vivier 2006), and then again for a 6 mo period from March until August 2007. The latter opening was not due to increased rainfall in the catchment, but to the extreme wave height associated with Cyclone Gamede, which broke the sandbar on the seaward side.

Previous phytoplankton studies undertaken in the St Lucia Estuary are limited to the taxonomic works by Cholnoky (1968), Grindley \& Heydorn (1970) and Millard \& Broekhuysen (1970), the cell volume survey by Johnson (1976), the examination of chlorophyll a (chl a) biomass by Fielding et al. (1991) and a recent taxonomic and ecological survey of the benthic and pelagic diatoms by Bate \& Smailes (2008).

The aim of the present study was, therefore, to quantify microalgal biomass in the water column (phyto- plankton) and sediment (microphytobenthos) during the present drought and to identify the mechanisms responsible for spatio-temporal patterns in microalgae across the whole system. This work is part of a broader programme aimed at understanding the biodiversity and ecological functioning of intermittently open and shallow estuaries. This is especially important in the context of the current escalation of alternating dry and wet cycles in response to climate change.

\section{MATERIALS AND METHODS}

Study area. The St Lucia Estuary is situated in northern KwaZulu-Natal, South Africa, and lies between $27^{\circ} 52^{\prime} \mathrm{S}$ and $28^{\circ} 24^{\prime} \mathrm{S}$ and $32^{\circ} 21^{\prime} \mathrm{E}$ and $32^{\circ} 34^{\prime} \mathrm{E}$. The estuary consists of 3 shallow interconnected lakes that discharge into the Indian Ocean via a $21 \mathrm{~km}$ long channel called the Narrows (Fig. 1). The system is generally subdivided into the Mouth, Narrows, South Lake, North Lake and False Bay. Normally, the estuary receives water from 5 rivers (Mpate, Mkuze, Mzinene, Hluhluwe and Nyalazi), as well as direct rainfall and ground water seepage flowing in from a high sand dune cordon lying between the eastern shores and the Indian Ocean (Fig. 1). Within historic times, freshwater has also been received from the Mfolozi River during droughts, when the lake level was very low (Taylor 2006). However, due to a very high silt load during floods arising from agricultural utilisation of the Mfolozi flood plain, the connection between the rivers has been artificially closed since 1952, in order to prevent excessive siltation of the estuary. As a result of the above factors, extremely shallow water levels, with an average depth down from the full level of $\sim 0.9$ to $0.46 \mathrm{~m}$ and a maximum depth of $3.5 \mathrm{~m}$, have prevailed during the peak of the drought.

During this period, poor water quality inside the estuarine lake was also exacerbated by wind-induced turbidity. Even light winds can cause strong mixing and wave action over the large, shallow water surface of the St Lucia Estuary (Forbes et al. 1987). The sediment granulometry of the system has been reported by Pillay \& Perissinotto (2008). In brief, sediments in the mouth region are composed of fine sand, becoming more silty in the northern parts of the Narrows. Sediments in the southern half of South Lake are a mixture of coarse and fine sand, but become finer further north into the system, being classified there as fine to coarse silt.

Fourteen stations were sampled regularly every $3 \mathrm{mo}$, from August 2004 to October 2005. After this initial phase of wide spatial cover, it was decided, on the basis of similarity analysis, that 1 station located on each side of the 3 lakes (False Bay, North Lake, South Lake) and another 2 each for the Narrows and Mouth included 


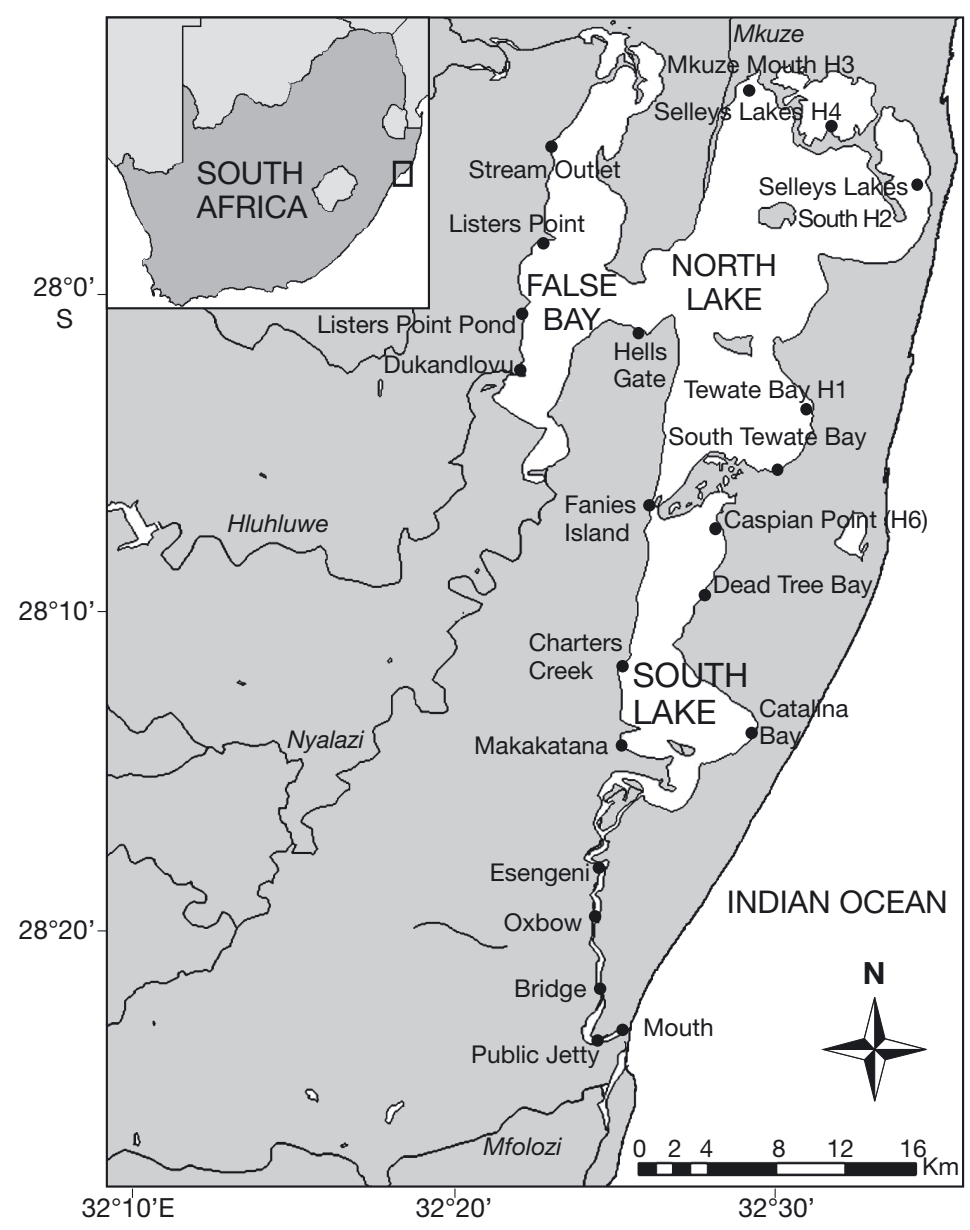

Fig. 1. Map of the St Lucia Estuary showing geographical positions of study sites. Stations at the Mouth, Public Jetty, Bridge, Oxbow, Esengeni, Makakatana, Charters Creek, Fanies Island, Hells Gate, Listers Point Pond, Listers Point, Stream Outlet, Catalina Bay and Dead Tree Bay were sampled at quarterly intervals from August 2004 to October 2005. Thereafter, only 5 of these stations (Mouth, Esengeni, Charters Creek, Listers Point, Catalina Bay) were sampled regularly until the end of the survey. Dukandlovu and South Tewate Bay were sampled only on 1 occasion, in August 2004, while Tewate Bay (H1), Selleys Lakes South (H2), Mkuze Mouth (H3), Selleys Lakes (H4) and Caspian Point (H6) were sampled by helicopter only in December 2006

most of the spatial diversity observed (Pillay \& Perissinotto 2008, Carrasco et al. 2010). Hence, from February 2006 until August 2007, 5 representative stations were sampled, viz. the Mouth, Esengeni (Narrows), Charters Creek (South Lake, western shore), Catalina Bay (South Lake, eastern shore) and Listers Point (False Bay). Another 5 stations, H1, H2, H3, H4 and H6 (Fig. 1) were sampled on only 1 occasion, in December 2006, using helicopter transport. More regular access to these areas, and the North Lake in general, was not possible due to the absence of roads and the extremely shallow water, which precluded the use of a boat.

Physico-chemical measurements. Water depth, temperature, salinity, dissolved oxygen and $\mathrm{pH}$ were mea- sured on each survey using either a YSI 556 or YSI 6920 Multiprobe system. Irradiance levels (photosynthetic available radiation [PAR], 400-700 nm) were measured using a LI-COR light meter, fitted either with a LI-189 or LI193SA quantum sensor. Physico-chemical variables were measured at the water subsurface, but also at the sediment-water interface at sites deeper than $50 \mathrm{~cm}$. Surface and bottom PAR were measured at all sites and were used to calculate the diffusive light attenuation coefficient $\left(K_{\mathrm{d}}\right)$, using the following equation: $K_{\mathrm{d}}=-\ln \left(I_{z 2} / I_{z 1}\right) /\left(z_{2}-z_{1}\right)$, where $I_{z 2}$ is irradiance $\left(\mathrm{mmol} \mathrm{m}^{-2} \mathrm{~s}^{-1}\right)$ at depth $z_{2}(\mathrm{~m})$ and $I_{z 1}$ is irradiance at depth $z_{1}$.

Samples of surface water and sediment porewater were collected for the measurement of dissolved inorganic nitrogen (DIN: nitrate + ammonia) and phosphorous (DIP: orthophosphate). Inorganic nutrient levels were measured by the Council for Scientific and Industrial Research (CSIR, Durban), using a Technicon II Autoanalyzer and following the methods of Mostert (1983).

Phytoplankton biomass. Water samples for the measurement of phytoplankton biomass (as chl a) were collected at the subsurface level on each sampling trip, while bottom samples were collected only at deeper sites, where depth exceeded $50 \mathrm{~cm}$. Aliquots of water (100 to $250 \mathrm{ml}$ ) were filtered on GF/F glass-fibre filters to determine the total autotrophic pelagic biomass. Phytoplankton was also size-fractionated by sequentially filtering known volumes of water samples through $20 \mu \mathrm{m}$ Nitex, $2.0 \mu \mathrm{m}$ Millipore and Whatman GF/F glass-fibre filters (Sieburth et al. 1978). After filtration, chl a was extracted by placing filters in $90 \%$ acetone for 24 to $48 \mathrm{~h}$ at $<5^{\circ} \mathrm{C}$. A Turner Designs 10-AU fluorometer fitted with a narrow-band, non-acidification system (Welschmeyer 1994) was used to measure chl a concentration.

Microphytobenthic biomass. Triplicate samples of the upper $10 \mathrm{~mm}$ of sediment were collected randomly within a distance of 1 to $5 \mathrm{~m}$ from each other with a Perspex twin-corer (internal diameter $=20 \mathrm{~mm}$ ) at each site; these were transferred to polyethylene bottles containing $30 \mathrm{ml}$ acetone $(90 \%)$ for chl a extraction, following the recommendations of Rodriguez (1993) and Nozais et al. (2001) for South African estuaries. Chl a concentrations were again measured by narrow-band fluorometry with a Turner Designs 10-AU fluorometer, after a 24 to $48 \mathrm{~h}$ period of chl a extraction. 
Statistical analysis. Cluster analysis was performed using the PRIMER (Plymouth Routines in Multivariate Ecological Research) V5 statistical package on both phytoplankton and microphytobenthic data, to determine spatial trends in their distribution within the St Lucia Estuary (Clarke \& Warwick 1994). Dendrograms were constructed from similarity matrices generated from Bray-Curtis similarities, using non-transformed and non-standardised biomass data. The groupings of sites from dendrograms were superimposed onto topographical maps of the St Lucia Estuary for visualisation. For univariate statistical testing, data were transformed $[\log (x+1)$ or arcsine], in order to approximate normality in distribution (Zar 1999). However, when this still did not result in normality of distribution or homogeneity of variance, non-parametric testing was used for specific analyses. Correlation analyses (Spearman) were performed between physico-chemical parameters and chl a biomass of phytoplankton and microphytobenthos to determine relationships between these variables. Partial correlations were also obtained from zero-order matrices, in order to exclude spurious relationships (Zar 1999). All univariate statistical tests were performed using SPSS V16.

\section{RESULTS}

\section{Physico-chemical environment}

During the study period, temperature ranged from 17.2 to $36.6^{\circ} \mathrm{C}$, with the lowest values generally recorded from June to August $\left(20.4 \pm 0.53^{\circ} \mathrm{C}, \mathrm{SE}\right)$ and the highest from November to February $\left(29.1 \pm 0.5^{\circ} \mathrm{C}\right.$, SE). Because of the shallowness of its water column, the lake region consistently exhibited the widest temperature ranges $\left(17.4\right.$ to $\left.36.6^{\circ} \mathrm{C}\right)$, while variations were more restricted in the deeper Narrows and Mouth areas $\left(18.6\right.$ to $\left.32.3^{\circ} \mathrm{C}\right)$.

A reversed-salinity gradient existed in the system from August 2004 until February 2006 (Fig. 2). During this period, salinity values at the Mouth and Narrows

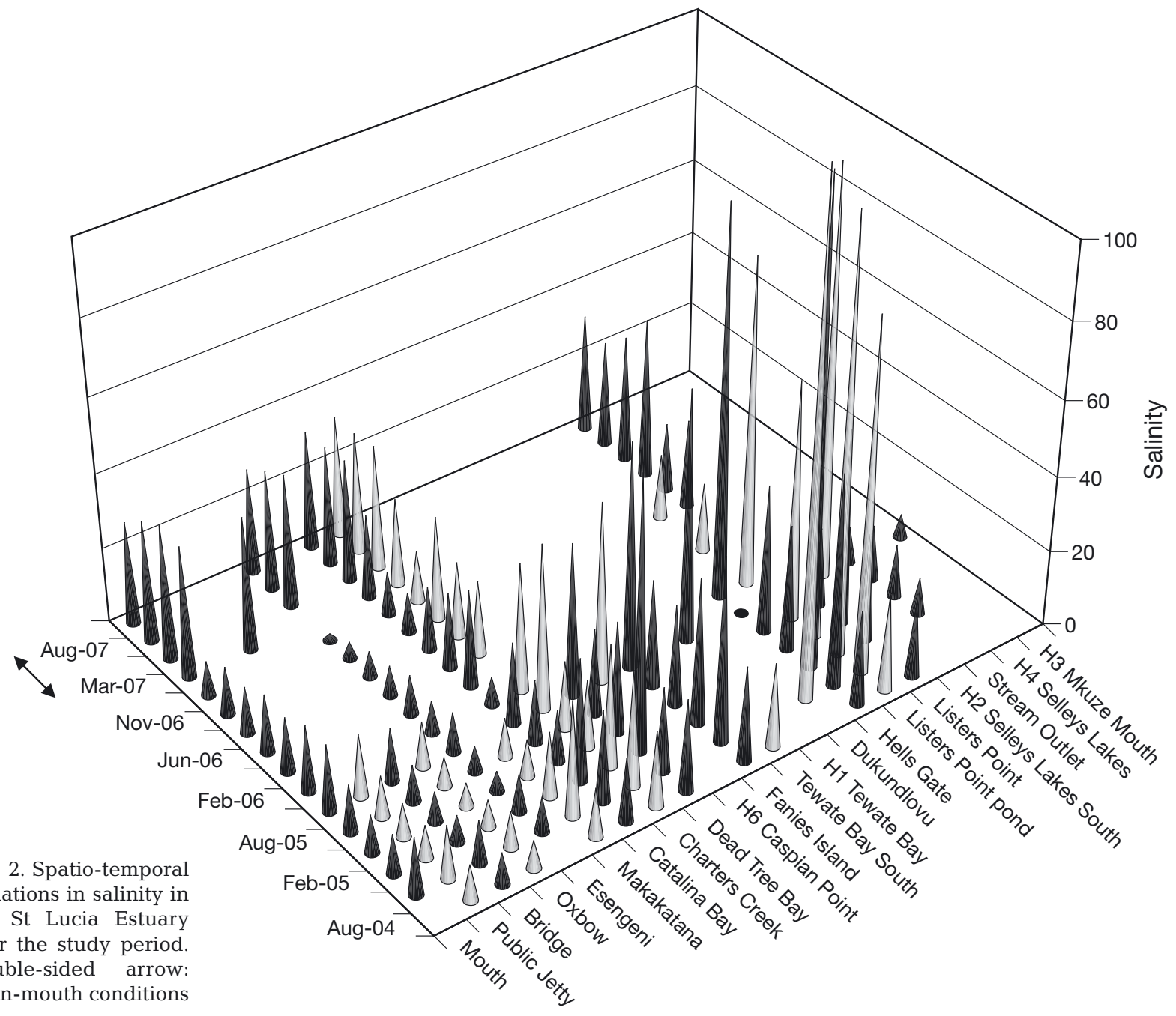

Fig. 2. Spatio-temporal variations in salinity in the St Lucia Estuary over the study period. Double-sided arrow: open-mouth conditions 
ranged from 5.3 to $17.9 \mathrm{psu}$, while in the South Lake and North Lake/False Bay regions these ranged from 7.4 to 59.9 psu and from 6.3 to 133.7 psu, respectively. Cases of extreme hypersalinity were prominent during this period, especially in South and North lakes, as well as False Bay (Fig. 2). Salinity levels were much less extreme during the remainder of the survey, with fewer records of hypersaline conditions reported between April 2006 and November 2007 (Fig. 2). During this latter period, at the Mouth and in the Narrows, salinity ranged from 1.8 to $36.4 \mathrm{psu}$, whereas in the South Lake and False Bay regions it ranged from 10.6 to $33.4 \mathrm{psu}$ and from 18.3 to $42.9 \mathrm{psu}$, respectively.

At most sampling sites, depth was generally $<0.2 \mathrm{~m}$ (Fig. 3). The only sites where water depth was consistently $>0.2 \mathrm{~m}$ were near the Mouth and in parts of the Narrows. As the drought intensified, the water in parts of the South and North lakes evaporated completely (Fig. 3). After 5 yr of uninterrupted closure, the estuary's mouth breached on 2 March 2007 and remained open continuously for almost 6 mo until 24 August
2007, despite continuing drought conditions. The breaching of the mouth was not related to rainfall, but was the result of very high seas caused by a regional cyclone, strong onshore winds and spring high tides. During this 6 mo open phase following the breach, the water level increased markedly as seawater flowed in, particularly in the driest parts of the lakes, where water depths virtually returned to their pre-drought state (Fig. 3).

Absolute and relative oxygen content in the water column was highly variable, ranging from 0.06 to $12.8 \mathrm{mg} \mathrm{l}^{-1}$ and 0.9 to $212 \%$, respectively, over the survey period. Hypoxic and anoxic conditions were recorded at Listers Point in February 2005 and November 2006, as well as at Listers Point Pond in November 2004 and 2006 and at Hells Gate in February 2005. Oxygen levels ranged between 5.4 and $12.8 \mathrm{mg} \mathrm{l}^{-1}$ (relative $\mathrm{O}_{2}$ range $=24$ to $170 \%$ ) in the Narrows, between 3.7 and $8.4 \mathrm{mg} \mathrm{l}^{-1}$ (0.9 to $163 \%$ ) in South Lake and between 0.06 and $12.6 \mathrm{mg} \mathrm{l}^{-1}$ (10.6 to $212 \%$ ) in the North Lake/False Bay region.

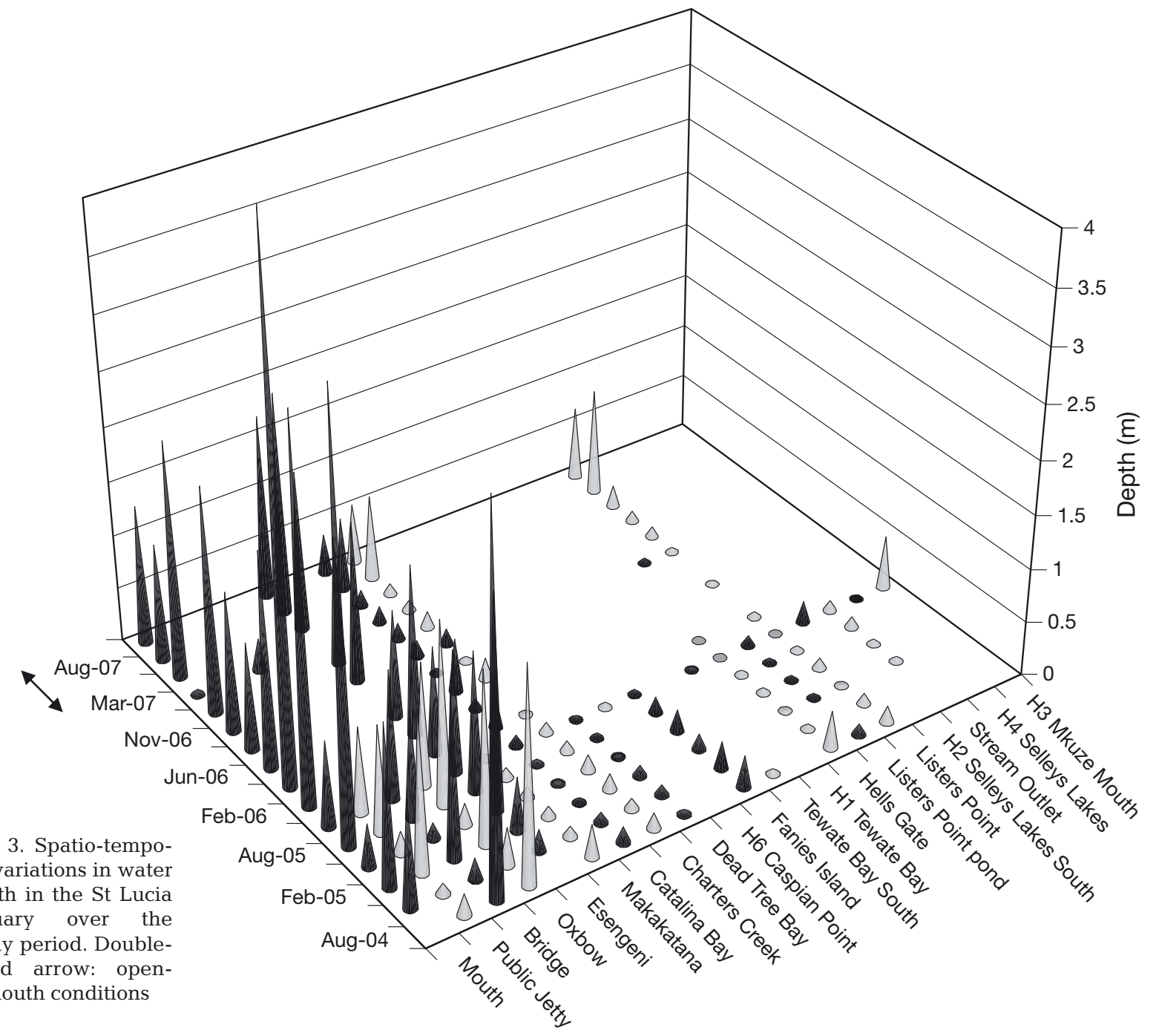


Throughout the estuary, surface irradiance varied between 3.59 and $2250 \mu \mathrm{mol} \mathrm{m}{ }^{-2} \mathrm{~s}^{-1}$, while bottom irradiance levels ranged between 0 and $1596 \mu \mathrm{mol} \mathrm{m}^{-2} \mathrm{~s}^{-1}$, in response to water depth and turbidity. Bottom irradiance averaged $271.5 \pm 135.5 \mu \mathrm{mol} \mathrm{m}^{-2} \mathrm{~s}^{-1}$ (surface light reaching the bottom: $81.8 \pm 2.5 \%$ ) at the Mouth and $40.63 \pm 14.4 \mu \mathrm{mol} \mathrm{m}^{-2} \mathrm{~s}^{-1}(94.6 \pm 1.34 \%)$ in the Narrows. This parameter increased towards the shallower northern regions, averaging $405.4 \pm 70.8 \mu \mathrm{mol} \mathrm{m}^{-2} \mathrm{~s}^{-1}$ $(70.2 \pm 2.9 \%)$ in South Lake and $410.8 \pm 93.4 \mu \mathrm{mol} \mathrm{m}^{-2}$ $\mathrm{s}^{-1}(59.6 \pm 4.5 \%)$ in North Lake. Light attenuation coefficients $\left(K_{\mathrm{d}}\right)$ peaked in the South Lake region of the system (Fig. 4). Coefficients varied between 0.4 and 20.3 in the Mouth and Narrows of the estuary, but ranged between 1.5 and 51.9 in South Lake and between 0.9 and 36.1 in the North Lake/False Bay area (Fig. 4).

Water-column DIN values ranged between 0.001 and $653 \mu \mathrm{M}$, while DIP ranged between 0.0001 and $4.65 \mu \mathrm{M}$ (Fig. 5A). The highest DIN concentrations were recorded during the period from November 2004 to February 2005 in the lakes region, particularly False
Bay, and under the most severe hypersaline conditions and shallowest water depth. The lowest DIN levels were observed from April to November 2006 in the lakes and again during May 2007 (open phase) in the Narrows and South Lake. The highest DIP levels, on the other hand, occurred in August 2004 in the North Lake region, while the lowest were observed in April 2006 and from February to August 2007 (open phase) virtually throughout the estuarine system. Porewater concentrations were about 5 -fold higher than watercolumn values, ranging between 3.36 and $1318 \mu \mathrm{M}$ for DIN and 0.097 and $36.8 \mu \mathrm{M}$ for DIP (Fig. 5B). Highest DIN levels were observed in August 2005 at False Bay and in June 2006 in the Narrows, while DIP was consistently higher in South Lake, in August 2004 and 2005 and again in March 2007. The lowest levels of porewater DIN and DIP occurred throughout the system in August 2004, 2007 and from February to October 2005, respectively (Fig. 5B). DIN:DIP ratios were well above the Redfield optimum of 16 for $60 \%$ of the time (mainly from June to November), but were below it only $27 \%$ of the time (mainly from February to May).

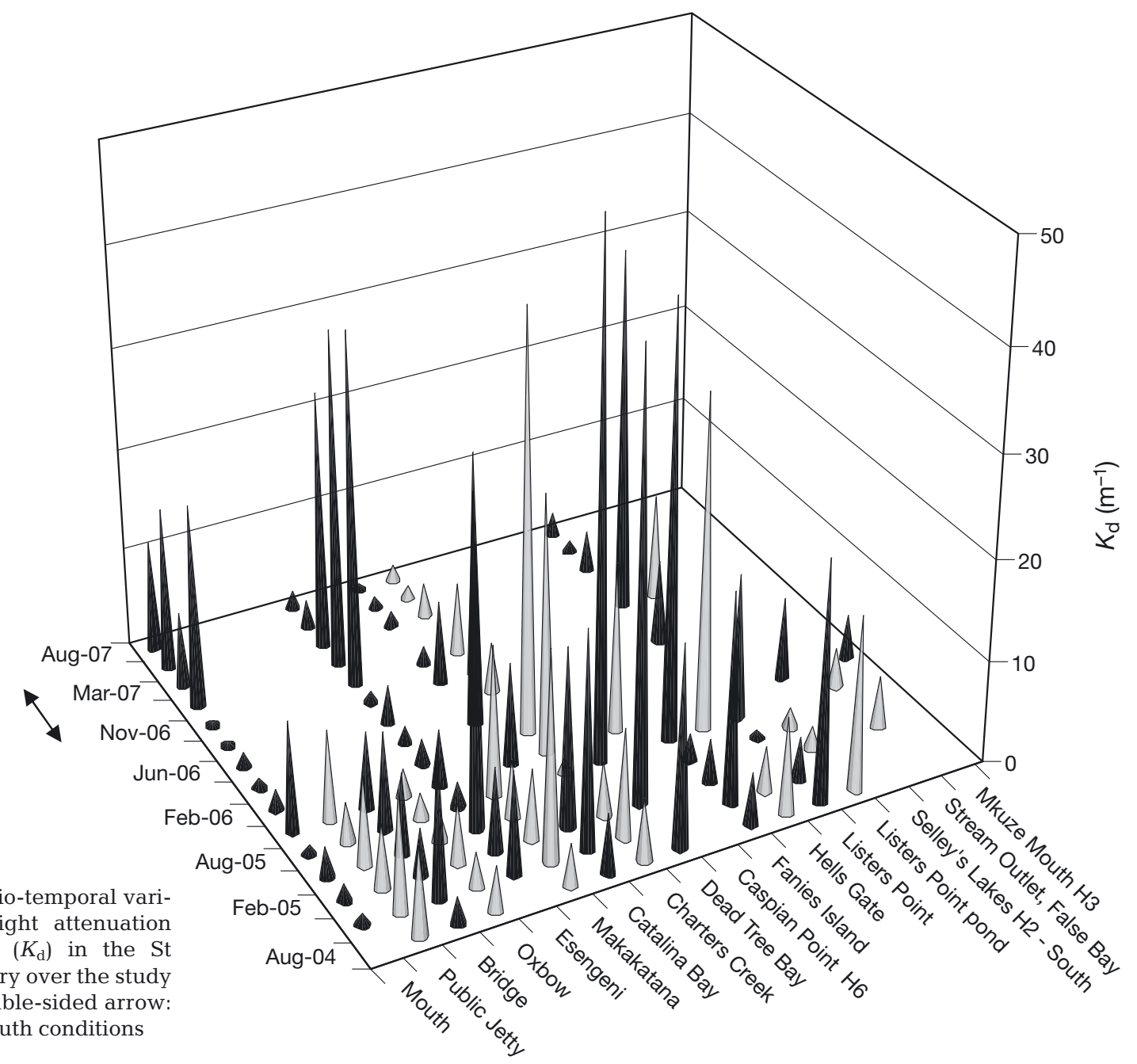

Fig. 4. Spatio-temporal variations in light attenuation coefficients $\left(K_{\mathrm{d}}\right)$ in the St Lucia Estuary over the study period. Double-sided arrow: open-mouth conditions 


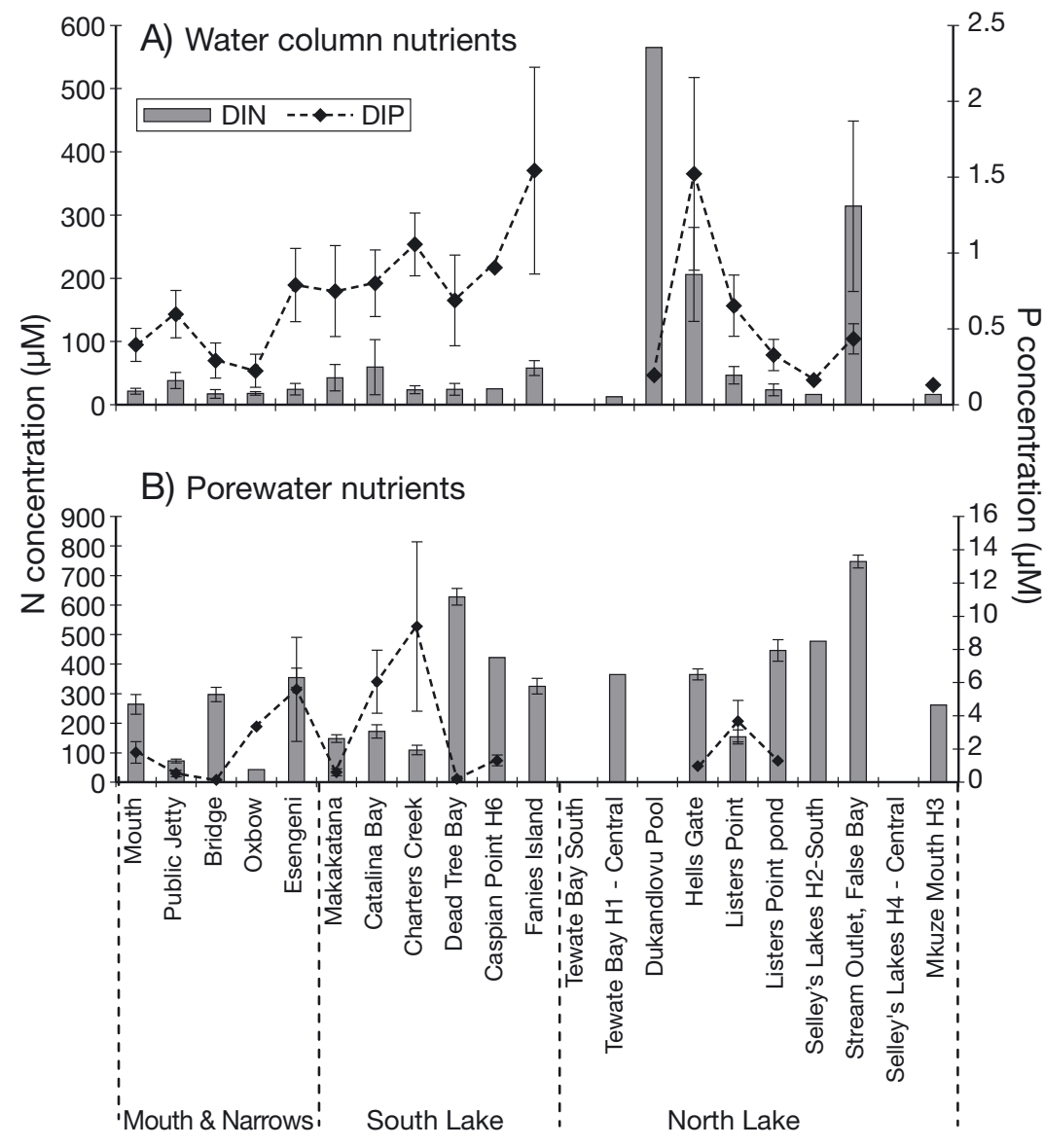

Fig. 5. Spatial differences in (A) water-column and (B) porewater nutrient concentrations in the St Lucia Estuary. Data are means $\pm 1 \mathrm{SE}$

(Fig. 8). This was followed by microphytoplankton $(>20 \mu \mathrm{m})$, with $18.5 \pm 19.9 \%$ (SD) and picophytoplankton $(<2 \mu \mathrm{m})$, with $17.7 \pm 15.2 \%(\mathrm{SD})$ of the total. Exceptions to the dominance of the nanophytoplankton size fraction occurred just prior to or after the period of mouth breaching (February, April and May 2007), as well as in August and November 2006, when pico- and microphytoplankton increased in abundance. At Tewate Bay Central, picophytoplankton was dominant, while microphytoplankton dominated at Tewate Bay South (Fig. 8).

Results from cluster analysis (Fig. 9A) show that the phytoplankton assemblages of the St Lucia Estuary could be subdivided into 2 distinct groups on the basis of their biomass. Phytoplankton Cluster 1 includes all stations in the region of the Narrows, Mouth and South Lake, as well as 2 stations in the northern area of North Lake and 3 others in the southern branch of False Bay (Fig. 9A). Phytoplankton Cluster 2 includes the northern branch of False Bay and the vast majority of North Lake sites.

The relationship between the physico-chemical parameters and all phytoplankton data pooled (Table 1) showed a positive association with dissolved oxygen ( $\mathrm{p}<0.05, \mathrm{R}=0.2$ ), water depth

\section{Microalgal biomass}

\section{Phytoplankton}

Water-column chl a concentrations were generally high (average $\pm \mathrm{SD}: 32.3 \pm 53.4 \mathrm{mg} \mathrm{m}^{-3}$ ), with values $>100 \mathrm{mg} \mathrm{m}^{-3}$ observed on at least 10 occasions (Fig. 6), mainly in the northern lakes region and from February to April and August to October. The highest value of $413 \mathrm{mg} \mathrm{m}^{-3}$ was recorded at Listers Point in False Bay on 27 February 2007, just prior to the mouth-breaching event. When integrated over water-column depth (i.e. concentration per unit volume multiplied by actual depth), chl a levels ranged from 0.02 to $537 \mathrm{mg} \mathrm{m}^{-2}$ (average $\pm \mathrm{SD}: 31 \pm 55 \mathrm{mg} \mathrm{m}^{-3}$; Fig. 7). The highest values were observed in the Narrows/Mouth region and the lowest in the lakes. In terms of size fractions, water-column chl a was generally dominated by nanophytoplankton (2 to $20 \mu \mathrm{m}$ ), which overall accounted for $63.7 \pm 24.1 \%$ (SD) of the total chl a biomass measured in the estuarine lake during the study period $(\mathrm{p}<0.001, \mathrm{R}=0.83)$ and surface irradiance $(\mathrm{p}<0.05, \mathrm{R}$ $=0.23$ ), but a negative association with salinity $(\mathrm{p}<$ $0.001, \mathrm{R}=-0.4), \mathrm{pH}(\mathrm{p}<0.01, \mathrm{R}=-0.25)$, bottom irradiance $(\mathrm{p}<0.001, \mathrm{R}=-0.49), K_{\mathrm{d}}(\mathrm{p}<0.05, \mathrm{R}=-0.24)$ and water-column DIP $(\mathrm{p}<0.05, \mathrm{R}=-0.2)$. Considering closed and open estuarine phases separately, phytoplankton biomass prior to the breaching event in March 2007 was positively correlated with dissolved oxygen ( $\mathrm{p}<0.01, \mathrm{R}=0.25)$, water depth $(\mathrm{p}<0.001, \mathrm{R}=$ $0.84)$ and surface irradiance $(p<0.01, R=0.26)$, but negatively with salinity $(\mathrm{p}<0.001, \mathrm{R}=-0.43), \mathrm{pH}(\mathrm{p}<$ $0.01, \mathrm{R}=-0.28)$, bottom irradiance $(\mathrm{p}<0.001, \mathrm{R}=$ $-0.54)$ and $K_{\mathrm{d}}(\mathrm{p}<0.01, \mathrm{R}=-0.3)$. During the open phase, phytoplankton biomass was significantly correlated only with water depth $(\mathrm{p}<0.001, \mathrm{R}=-0.79)$.

Partial correlation analysis (Table 2) showed that water depth was always positively correlated with phytoplankton biomass, irrespective of which variable was held constant $(p<0.01)$. Porewater DIN was also positively associated with phytoplankton biomass, except when water depth was controlled. 


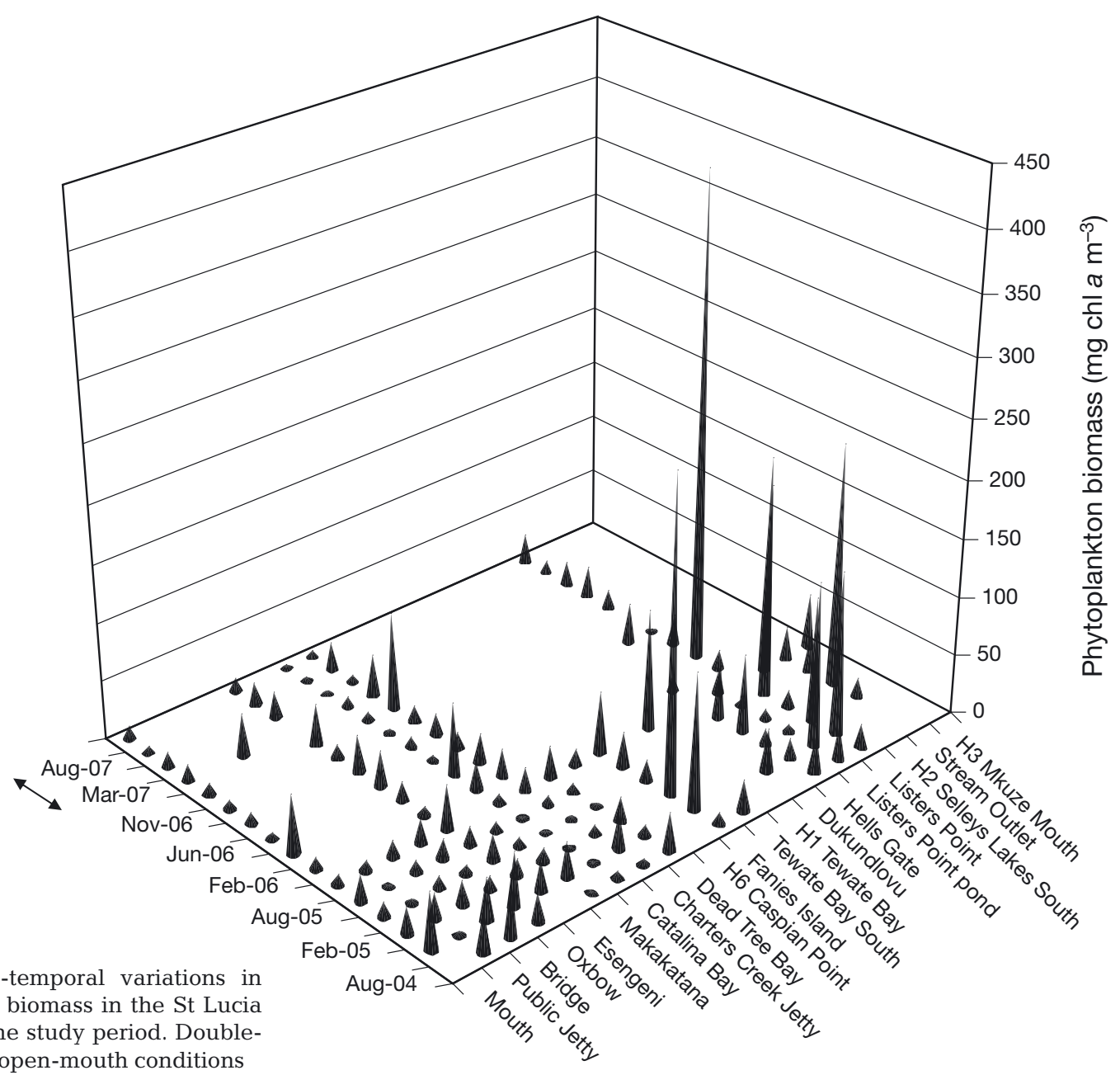

Fig. 6. Spatio-temporal variations in phytoplankton biomass in the St Lucia Estuary over the study period. Doublesided arrow: open-mouth conditions

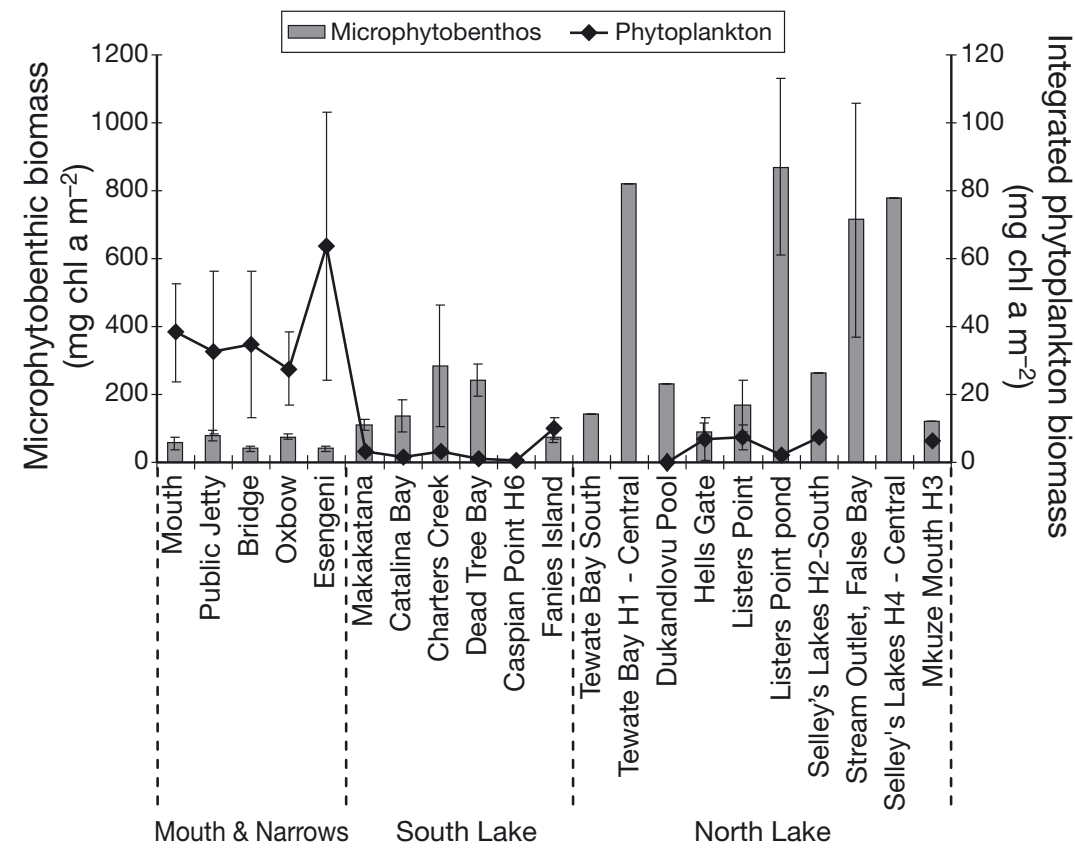

Fig. 7. Spatial differences in microphytobenthic and integrated phytoplankton biomass in the St Lucia Estuary. Data are means \pm 1 SE
Microphytobenthos

Microphytobenthic biomass (as chl a) was consistently much higher in the lake regions than in the Narrows or at the Mouth (Fig. 10). The average ( \pm SD) value for the entire estuarine complex was $201 \pm 377 \mathrm{mg} \mathrm{m}^{-2}$, with the highest value of $2576 \mathrm{mg} \mathrm{m}^{-2}$ measured at Charters Creek in March 2007, and the lowest of $1.24 \mathrm{mg} \mathrm{m}^{-2}$, at the Mouth in August 2006. Values in excess of $1000 \mathrm{mg}$ $\mathrm{m}^{-2}$ were recorded on at least 5 occasions at Listers Point (False Bay) and Charters Creek (South Lake), during the period from February to April 2005 and March 2007 (Figs. 7 \& 10). Compared to biomass levels in the water column (integrated over water depth, i.e. $\mathrm{mg} \mathrm{m}^{-2}$ ), microphytobenthic biomass was on average $( \pm$ SD) 6.5 -fold $( \pm 6.8)$ higher (Fig. 7). However, at deep stations ( 1 to $4 \mathrm{~m}$ ) in the Narrows and at the 


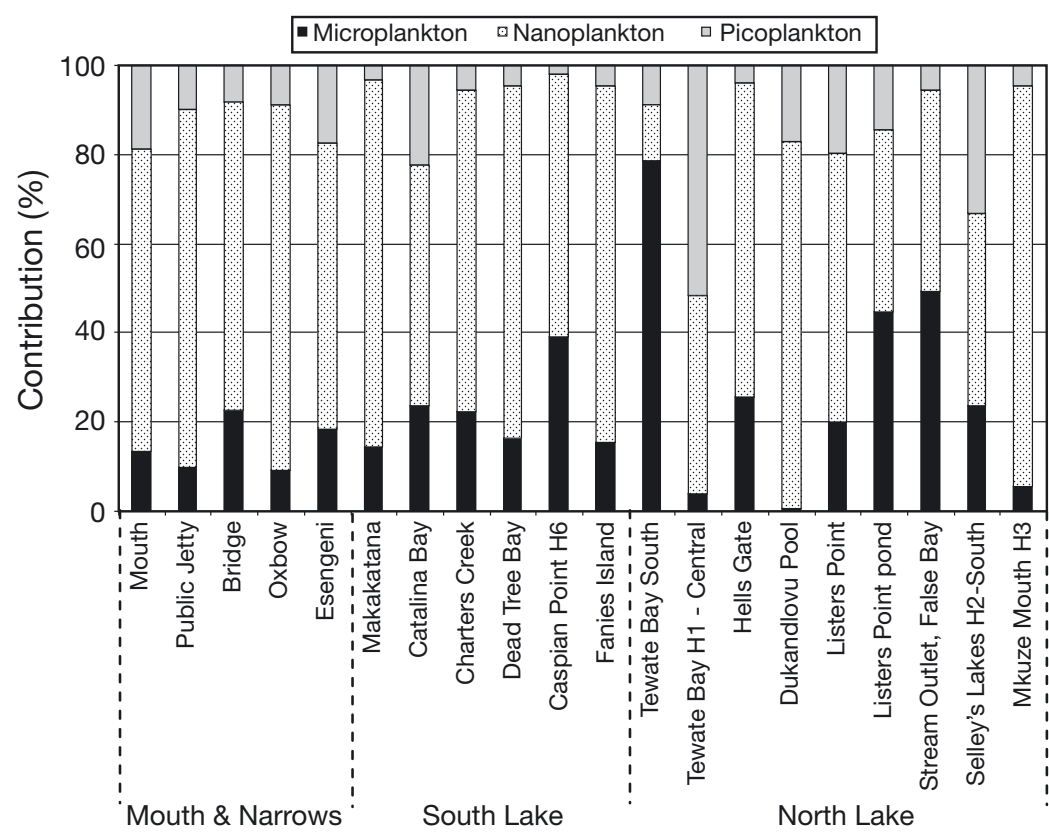

Fig. 8. Spatial variations in size fractions of phytoplankton in the St Lucia Estuary during the study period
A) Phytoplankton

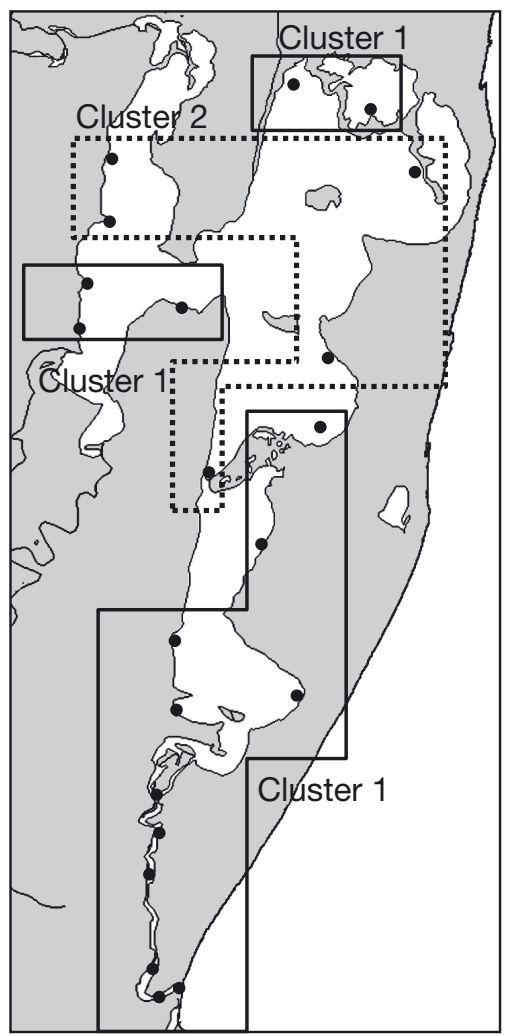

\section{B) Microphytobenthos}

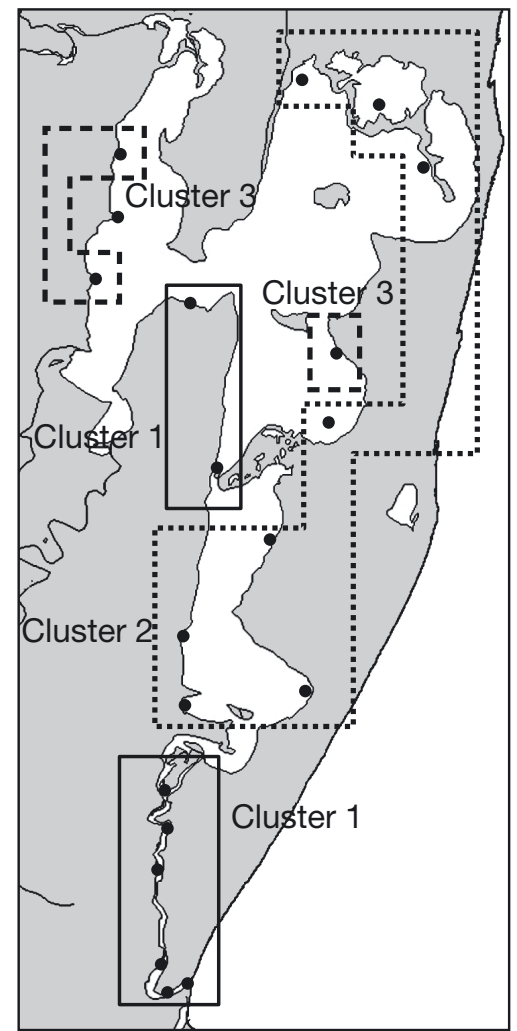

Fig. 9. Maps of the St Lucia Estuary with the major (A) phytoplankton and (B) microphytobenthic groups, as identified by cluster analysis
Mouth, this pattern was often reversed, with values being 1.02- to 11.6-fold higher in the water column than in the sediment. Water-column and sediment microalgal biomass levels were negatively correlated with each other during the study period ( $\mathrm{p}<0.001, \mathrm{R}=-0.39$ ).

The microphytobenthos data revealed 3 clusters. Microphytobenthos Cluster 1 includes the areas of the Narrows and Mouth, as well as the western shores of North Lake. Microphytobenthos Cluster 2 includes South Lake and all of the eastern shores of North Lake, with the exception of Tewate Bay (H1), while Microphytobenthos Cluster 3 includes Tewate Bay (H1) and False Bay (Fig. 9B).

Microphytobenthic biomass was positively correlated with salinity $(\mathrm{p}<0.05$, $\mathrm{R}=0.2$ ) and water-column irradiance ( $p<0.05, R=0.26)$, but negatively with water depth $(\mathrm{p}<0.001, \mathrm{R}=-0.45$; Table 1). During the closed phase, microphytobenthic biomass was positively associated with irradiance ( $\mathrm{p}<$ $0.05, \mathrm{R}=0.27)$ and salinity $(\mathrm{p}<0.01, \mathrm{R}=$ $0.25)$, but negatively with water depth $(p<0.001, R=-0.44)$. When the estuary mouth breached in 2007, microphytobenthic biomass was positively correlated with water temperature $(\mathrm{p}<0.05$, $\mathrm{R}=0.7)$, dissolved oxygen $(\mathrm{p}<0.01, \mathrm{R}=$ $0.85)$ and porewater DIP $(\mathrm{p}<0.001, \mathrm{R}=$ $0.9)$, but negatively with water depth ( $\mathrm{p}<0.05, \mathrm{R}=-0.85$; Table 1$)$.

Partial correlation analysis (Table 2) showed that microphytobenthic biomass was positively correlated with water-column DIN when water-column DIP ( $p<0.01, R=0.69$ ) and porewater DIP ( $p<0.05, R=0.56$ ) were controlled, and with water-column DIP when water-column DIN was held constant ( $\mathrm{p}<0.05, \mathrm{R}=0.62)$.

\section{DISCUSSION}

St Lucia water-column chl a concentrations averaged $( \pm \mathrm{SD}) 32.3 \pm 53.4 \mathrm{mg} \mathrm{m}^{-3}$, and the highest value of $413 \mathrm{mg} \mathrm{m}^{-3}$ was recorded at Listers Point in False Bay on 27 February 2007, just prior to the mouth-breaching event. Within the sediment, the average $( \pm \mathrm{SD})$ microphyto- 
Table 1. Summary statistics of correlation analysis (Pearson) between environmental variables and chlorophyll a biomass of microphytobenthos and phytoplankton prior to, during and after breaching of the St Lucia Estuary. Analyses were also performed on data pooled across all sampling seasons. Values in bold indicate statistically significant relationships at the 0.05 level of significance. PAR: photosynthetic available radiation; DIP: dissolved inorganic phosphorus; DIN: dissolved inorganic nitrogen; $K_{\mathrm{d}}$ : diffusive light attenuation coefficient

\begin{tabular}{|c|c|c|c|c|c|c|c|}
\hline \multirow[t]{2}{*}{ Variable } & & \multicolumn{2}{|c|}{$\longrightarrow$ Open } & \multicolumn{2}{|c|}{$\longrightarrow$ Closed } & \multicolumn{2}{|c|}{$\longrightarrow$ Pooled } \\
\hline & & Microphytobenthos & Phytoplankton & Microphytobenthos & Phytoplankton & Microphytobenthos & Phytoplankton \\
\hline \multirow[t]{2}{*}{ Salinity } & $\mathrm{R}$ & -0.35 & 0.055 & 0.252 & -0.43 & 0.22 & -0.399 \\
\hline & $\mathrm{p}$ & 0.31 & 0.88 & 0.007 & $<0.0001$ & 0.014 & $<0.0001$ \\
\hline \multirow[t]{2}{*}{ Temperature } & $\mathrm{R}$ & 0.7 & -0.28 & 0.094 & -0.146 & 0.132 & -0.151 \\
\hline & $\mathrm{p}$ & 0.022 & 0.42 & 0.319 & 0.121 & 0.144 & 0.093 \\
\hline \multirow[t]{2}{*}{$\mathrm{pH}$} & $\mathrm{R}$ & 0.6 & -0.079 & 0.021 & -0.284 & 0.067 & -0.24 \\
\hline & $\mathrm{p}$ & 0.067 & 0.82 & 0.822 & 0.002 & 0.46 & 0.005 \\
\hline \multirow{2}{*}{$\begin{array}{l}\text { Dissolved oxygen } \\
\text { (absolute) }\end{array}$} & $\mathrm{R}$ & 0.85 & -0.41 & -0.113 & 0.25 & -0.029 & 0.203 \\
\hline & $\mathrm{p}$ & 0.002 & 0.22 & 0.235 & 0.007 & 0.74 & 0.024 \\
\hline \multirow[t]{2}{*}{ Turbidity } & $\mathrm{R}$ & -0.308 & -0.11 & -0.022 & -0.07 & -0.11 & -0.034 \\
\hline & $\mathrm{p}$ & 0.38 & 0.75 & 0.89 & 0.659 & 0.46 & 0.81 \\
\hline \multirow[t]{2}{*}{ Water depth } & $\mathrm{R}$ & -0.65 & 0.79 & -0.44 & 0.84 & -0.45 & 0.838 \\
\hline & $\mathrm{p}$ & 0.041 & 0.006 & $<0.0001$ & $<0.0001$ & $<0.0001$ & $<0.0001$ \\
\hline \multirow[t]{2}{*}{ PAR (bottom) } & $\mathrm{R}$ & 0.1 & -0.1 & 0.27 & -0.54 & 0.26 & -0.49 \\
\hline & $\mathrm{p}$ & 0.777 & 0.798 & 0.012 & $<0.0001$ & 0.011 & $<0.0001$ \\
\hline \multirow[t]{2}{*}{ PAR (surface) } & $\mathrm{R}$ & -0.43 & 0.55 & 0.03 & 0.25 & 0.018 & 0.232 \\
\hline & $\mathrm{p}$ & 0.21 & 0.12 & 0.76 & 0.008 & 0.85 & 0.013 \\
\hline \multirow{2}{*}{$\begin{array}{l}\text { Percent light } \\
\text { at bottom }\end{array}$} & $\mathrm{R}$ & -0.59 & 0.267 & -0.106 & -0.281 & -0.09 & -0.306 \\
\hline & $\mathrm{p}$ & 0.091 & -0.34 & 0.293 & 0.004 & 0.307 & 0.001 \\
\hline \multirow[t]{2}{*}{ Porewater DIN } & $\mathrm{R}$ & -0.5 & 0.46 & 0.04 & -0.15 & -0.059 & -0.09 \\
\hline & $\mathrm{P}$ & 0.17 & 0.17 & 0.76 & 0.26 & 0.661 & 0.48 \\
\hline \multirow[t]{2}{*}{ Porewater DIP } & $\mathrm{R}$ & 0.91 & -0.28 & -0.09 & -0.06 & 0.11 & -0.164 \\
\hline & $\mathrm{p}$ & 0.001 & 0.43 & 0.55 & 0.6 & 0.43 & 0.246 \\
\hline \multirow{2}{*}{$\begin{array}{l}\text { Water-column } \\
\text { DIN }\end{array}$} & $\mathrm{R}$ & -0.28 & 0.46 & 0.10 & -0.149 & 0.058 & -0.087 \\
\hline & $\mathrm{P}$ & 0.45 & 0.17 & 0.25 & 0.11 & 0.525 & 0.334 \\
\hline \multirow{2}{*}{$\begin{array}{l}\text { Water-column } \\
\text { DIP }\end{array}$} & $\mathrm{R}$ & 0.57 & -0.28 & -0.035 & -0.17 & 0.012 & -0.202 \\
\hline & $\mathrm{p}$ & 0.1 & 0.43 & 0.72 & 0.057 & 0.89 & 0.024 \\
\hline \multirow[t]{2}{*}{$K_{\mathrm{d}}$} & $\mathrm{R}$ & -0.6 & 0.6 & 0.049 & -0.304 & 0.045 & -0.24 \\
\hline & $\mathrm{p}$ & 0.28 & 0.28 & 0.65 & 0.005 & 0.67 & 0.021 \\
\hline
\end{tabular}

benthic chl a concentration value measured at St Lucia during this study was $201 \pm 377 \mathrm{mg} \mathrm{m}^{-2}$, with the highest value of $2576 \mathrm{mg} \mathrm{m}^{-2}$ recorded at Charters Creek in March 2007. Both maxima are among the highest values so far reported in the literature for any estuarine ecosystem, including those impacted by eutrophication (Lukatelich \& McComb 1986, Cloern 1996, Adams et al. 1999, Underwood \& Kromkamp 1999, Livingston 2001, McLusky \& Elliott 2004, Thomas et al. 2005, Perissinotto et al. 2006). In a South African context, these are by far the highest values reported for any estuary. Maximum phytoplankton biomass in the St Lucia Estuary was roughly 4 times greater than maximum values recorded for permanently open systems, where greatest values exceed $20 \mathrm{mg} \mathrm{m}^{-3}$ and may reach $100 \mathrm{mg} \mathrm{m}^{-3}$ on occasions (Adams et al. 1999). Highest phytoplankton concentrations were also up to 50 times greater at St Lucia, relative to values observed in smaller temporarily open/closed systems, such as the Mdloti Estuary
(0.09 to $8.6 \mathrm{mg} \mathrm{m}^{-3}$; Nozais et al. 2001) and the Mpenjati Estuary ( 0.14 to $15 \mathrm{mg} \mathrm{m}^{-3}$; Perissinotto et al. 2002 and references therein). Similarly, highest microphytobenthic biomass values in the St Lucia Estuary were between 5 and 7 times greater than those reported for the temporarily open/closed Mdloti Estuary (1.4 to $480 \mathrm{mg}$ $\mathrm{m}^{-2}$; Nozais et al. 2001) and the Mpenjati Estuary (19.6 to $616 \mathrm{mg} \mathrm{m}^{-2}$; Perissinotto et al. 2002), and up to 11 times greater than reported for the permanently open Great Brak (85 to $297 \mathrm{mg} \mathrm{m}^{-2}$; Adams et al. 1999).

The average values are, however, within the range of those reported from several other estuaries, although generally at the higher end. For instance, Lukatelich \& McComb (1986) working in the shallow Peel-Harvey estuarine system (Western Australia) measured average benthic microalgal biomass values of between 100 and $200 \mathrm{mg} \mathrm{m}^{-2}$, which are on the same order of magnitude as the St Lucia data. McLusky \& Elliott's (2004) review of mean values for estuaries 


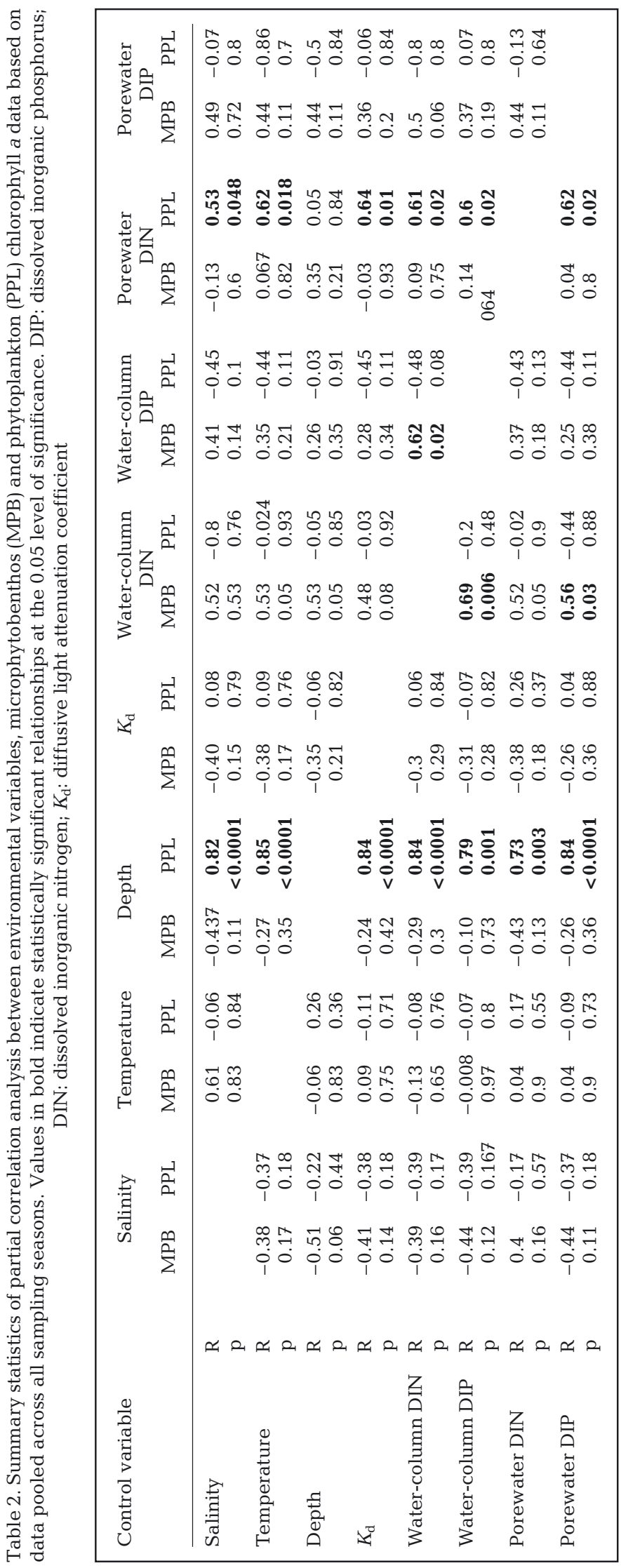

around the world shows a range of from 10 to $500 \mathrm{mg} \mathrm{m}^{-2}$, with the highest individual value of $500 \mathrm{mg} \mathrm{m}^{-2}$ in the Bay of Fundy, Canada. The value measured at Charters Creek of $2576 \mathrm{mg} \mathrm{m}^{-2}$ must, therefore, be close to a record high and the result of unusual circumstances. Preliminary measurements with a BBE Fluoroprobe (Moldaenke), have indicated that the bulk of this exceptional microphytobenthic chl a peak may have been due to mats of cyanobacteria, which are adapted to taking advantage of the extreme conditions that regularly develop in the area. The phytoplankton biomass data for St Lucia, when integrated over the entire water column, showed chl a levels of between 0.02 to $537 \mathrm{mg} \mathrm{m}^{-2}$ of water surface area (average $\pm \mathrm{SD}$ : $31 \pm 55 \mathrm{mg} \mathrm{m}^{-2}$ ). These values are very similar to those for the Peel-Harvey Estuary (Australia), which also spiked occasionally to around $600 \mathrm{mg}$ $\mathrm{m}^{-2}$ of water surface area (Lukatelich \& McComb 1986). On average, biomass values in the water column in the Australian system were about 40 times lower than on the sediment. Comparison of water-column versus sediment values at St Lucia shows that areal phytoplankton biomass provided the greatest contribution at the Mouth and the Narrows, but then declined in South and North Lakes (Fig. 7). Microphytobenthos showed the reverse trend, with biomass peaking in South and North Lakes, but declining in the region of the Mouth and Narrows.

Clear patterns from ordinations and cluster analyses emerged, showing that phytoplankton biomass was spatially distinct between the southern and northern halves of the system, while microphytobenthic biomass was generally different between the Narrows and the rest of the system (Fig. 9). The relatively coarse sampling frequency that was adopted in the present study did, however, result in occasional odd distributions and clustering anomalies (e.g. microphytobenthic Cluster 3 in 2 separate positions). The spatial pattern in both microalgal groups was correlated with spatial differences in salinity, water depth and bottom irradiance, with dissolved oxygen, $\mathrm{pH}, K_{\mathrm{d}}$ and DIP additionally correlating with phytoplankton biomass. Light availability is a key factor influencing aquatic microalgae (Nozais et al. 2001), which is itself dependent on water depth and turbidity (Cahoon 1999). It is very likely that the reduced water depth enhanced light penetration in the northern regions of the system, leading to a proliferation of microalgae, while the greater water depth and higher mean turbidity at the Mouth, Narrows and South Lake may have inhibited microalgal growth in these areas. 


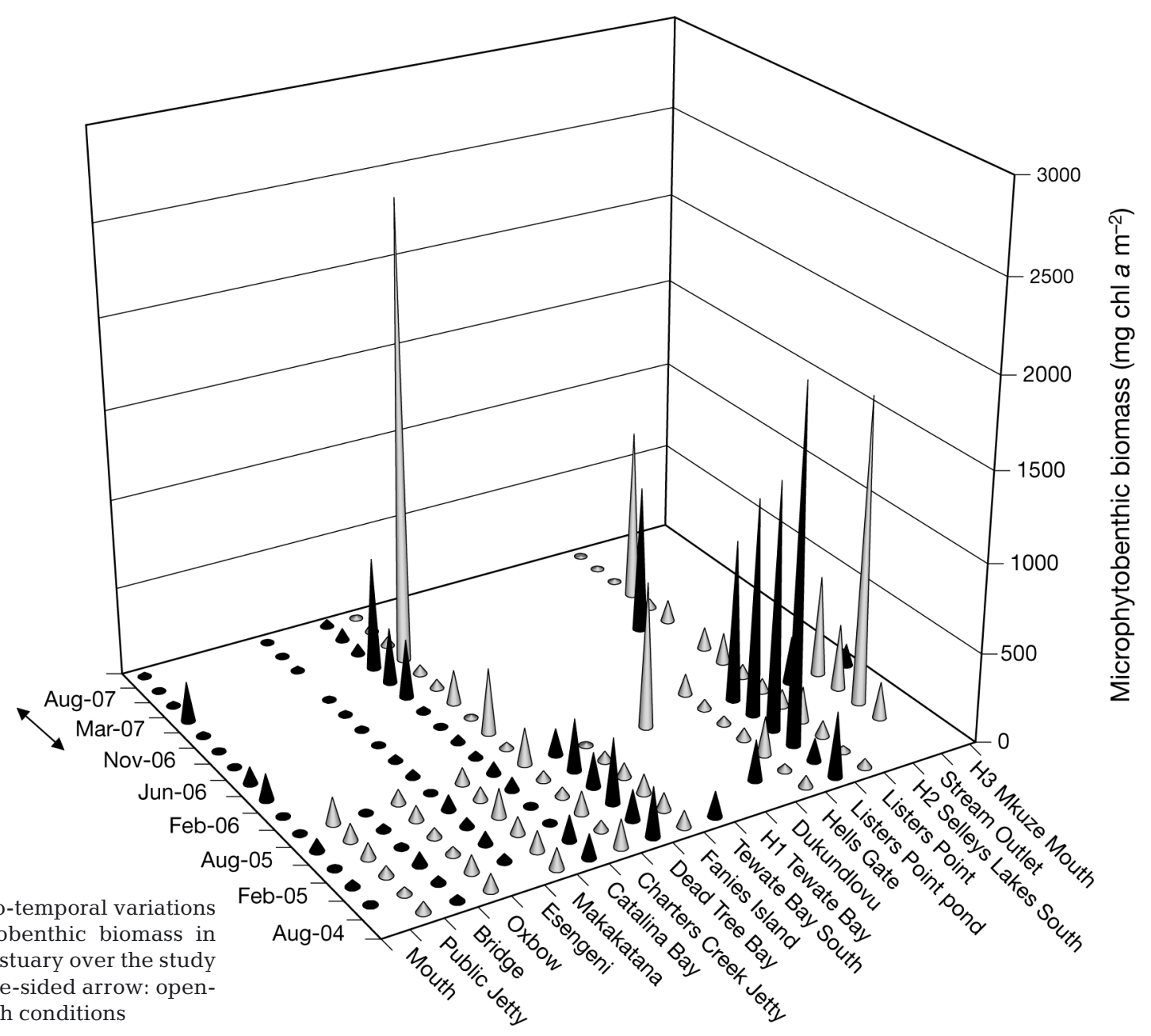

Fig. 10. Spatio-temporal variations in microphytobenthic biomass in the St Lucia Estuary over the study period. Double-sided arrow: openmouth conditions

Other factors that may have played an important role in the observed microalgal distribution pattern are temperature and salinity. The temperature trend measured in the system was not unexpected, being lowest during winter and highest in summer. However, the range of temperatures was mostly controlled by water depth, with deeper areas being least sensitive to fluctuation. As a result, in the shallowest portions of the lakes, temperatures reached almost $50^{\circ} \mathrm{C}$ during the hottest summer days. The reversed salinity gradient observed from August 2004 until February 2006 was mostly the result of small freshwater inflow to the Narrows from seepage and small streams. Being wide and shallow, the lakes region, and especially False Bay, had a greater tendency to become hypersaline during droughts, because the rivers did not flow. Under normal rainfall conditions, the highest salinity can be expected near the mouth (Forbes \& Cyrus 1993). The water at most sampling sites during the study was very shallow, being generally $<0.2 \mathrm{~m}$. On many occasions, wind-driven lateral water circulation could be observed, especially in the shallow lake areas. It is possible that this water movement is responsible for some of the data that were measured and the patterns that were formed.

Grazing by invertebrates is also known to affect microalgal biomass in estuaries and other aquatic ecosystems (Nichols 1985, Kibirige \& Perissinotto 2003). In temporarily open/closed estuaries, for example, the dominant zooplankton species can graze up to $69 \%$ of the available phytoplankton, and the chl a ingested can occasionally exceed $100 \%$ of the phytoplankton production (Kibirige \& Perissinotto 2003). Likewise, it has been demonstrated that benthic macrofauna in northern San Francisco Bay may have been responsible for declines in local phytoplankton biomass during drought conditions (Nichols 1985). This latter author estimated that a suspension-feeding bivalve population could have cleared all particles (including diatoms) in the water column, at least once a day (Nichols 1985). Pillay \& Perissinotto (2008) demonstrated that the total abundance of macrofauna was negatively correlated with microphytobenthic biomass in the St Lucia 
Estuary during the 2005 drought phase. In some hypersaline regions macroinvertebrates were absent, but microphytobenthos flourished. The authors suggested that the lack of grazing control may have been responsible for the high microphytobenthic biomass recorded, especially in the northern regions (Pillay \& Perissinotto 2008). Carrasco et al. (2010) also showed an inverse correlation between density and biomass of zooplankton with microphytobenthic biomass. Given these findings, reductions in grazing pressure mediated by extreme environmental conditions may be an important mechanism by which droughts influence microalgal biomass in the system.

Mouth state is known to be a major structuring agent of estuarine communities, and significantly affected physico-chemical dynamics in the St Lucia Estuary, leading to major impacts on microalgal groups. In similar situations along the Uruguayan coast, Bonilla et al. (2005) found that mouth breaching had an overwhelming effect on the phytoplankton of coastal lagoons only periodically connected with the Atlantic Ocean. They suggested that the large-scale variations, induced by the hydrodynamic events that follow a change in mouth state, are more important than seasonal and spatial differences. Prior to the opening of the St Lucia Estuary in 2007, salinity, water depth and bottom irradiance were the main factors affecting microphytobenthic biomass, while water-column nitrogen (DIN) concentration mainly affected phytoplankton biomass. When the system breached, none of the environmental variables correlated with phytoplankton biomass, but $K_{\mathrm{d}}$ correlated with microphytobenthic biomass. When the system closed again, water temperature and depth, along with DIP in the water column, correlated best with microphytobenthic biomass, but none of the variables measured correlated with phytoplankton biomass (Table 1). When data were pooled, salinity, water depth, bottom irradiance and $K_{\mathrm{d}}$ correlated best with microphytobenthic biomass, while bottom irradiance and DIN correlated best with phytoplankton biomass. Partial correlation analysis indicated that water depth was the overriding factor affecting microphytobenthic biomass, over and above the effects of both salinity and temperature (Table 2). None of these variables correlated with phytoplankton biomass.

Overall, DIN:DIP ratios were greater than the Redfield optimum of 16 for $60 \%$ of the time, and $27 \%$ of the time they were lower than this value. This indicates that microalgal production in the St Lucia Estuary may be limited by availability of either $\mathrm{P}$ or $\mathrm{N}$ for a substantial part of the year. However, in estuarine waters, it is unlikely that nutrient limitation sets in until DIN and DIP concentrations fall below thresholds of about 2 and $0.2 \mu \mathrm{M}$, respectively (Fisher et al. 1992). Similar threshold values during the current study were ob- served only $15 \%(\mathrm{~N})$ to $33 \%(\mathrm{P})$ of the time in the water column and even less frequently in porewater (1.5 and $5.7 \%$, respectively). Primary production measurements, conducted recently in the estuary, indicate that P-limitation may occur predominantly from June to November, while N-limitation mainly occurs from February to May (van der Molen \& Perissinotto unpubl. data). This would result in a summer productivity peak during the period of transition from P- to N-limitation. The question of where the high levels of DIN and DIP come from was partly answered by Johnson (1976), who showed that the total $\mathrm{N}$ input from rivers in the northern lakes was significant, i.e. up to $44 \mu \mathrm{M}$ from the Nyalazi River and $42 \mu \mathrm{M}$ from the Hluhluwe River, and that during a period of high inflow in October 1973 the $\mathrm{N}$ concentration in the lake rose from 8.6 to $14.3 \mu \mathrm{M}$. These values are far lower than the high value of $653 \mu \mathrm{M}$ measured during the present study, but it must be remembered that the very high values were recorded in False Bay when water levels were at their lowest, with ongoing evaporation increasing concentrations further. Johnson (1976) reported that P values in the lake fluctuated between 0.3 and $1.3 \mu \mathrm{M}$, but that river water flowing in had a much lower concentration than that of the lake, the implication being that high river inflow periods tend to lower $\mathrm{P}$ concentrations. During the present study, mineralisation of animal wastes, with a reduction in uptake because of the very high salinity values, was also likely.

The St Lucia Estuary is regarded as one of the most dynamic and extreme systems in Africa. The present study has confirmed this estimation, showing exceptionally high variability at both long (years) and medium (months) temporal scales, with respect to the physico-chemical environment and microalgal biomass. Given that microalgae form the base of planktonic and benthic food webs in the St Lucia Estuary (Govender unpubl. data), it is likely that their dynamics may ripple up food webs and explain, at least in part, the dynamic and often extreme nature of the higher trophic levels of this system. The estuary is currently undergoing an unprecedented crisis in terms of its conservation and management because of a prolonged drought, which has so far resulted in (1) $7 \mathrm{yr}$ of semi-continuous mouth closure, (2) water levels below mean sea level and (3) extreme hypersaline conditions (Taylor 2006, Pillay \& Perissinotto 2008, 2009, Carrasco et al. 2010). Alternation of dry and wet cycles are not new to this estuary, as regular occurrences of 4 to $10 \mathrm{yr}$ cycles of either droughts or anomalous wet conditions have been documented since at least the early 1900s (Taylor 2006). Projections of climate change for the next 50 to $100 \mathrm{yr}$ indicate that this situation will deteriorate even further, with the most likely scenario being an alternation of extreme droughts followed by floods 
(Schulze 2006). It will be important to monitor changes in microalgal productivity and biomass through these developments, as they may provide valuable early warning signals for the sustainable management of this unique ecosystem.

Acknowledgements. The present study was funded by grants from the National Research Foundation (NRF, Pretoria), Marine \& Coastal Management (MCM, Cape Town) and the World Wide Fund (WWF-SA, Stellenbosch). We are very grateful to the management and staff of Ezemvelo KZN Wildlife and the iSimangaliso Wetlands Park, for providing logistical support during the study. Special thanks go to R. Taylor, C. Fox and the late A. Myeza for their invaluable assistance with field operations. M. Olbers, S. Singh, K. Pillay, N. Govender, A. J. Smit, N. Carrasco, N. Miranda, R. Lawrie and C. Chrystal are also thanked for their assistance with data \& sample collection and analysis.

\section{LITERATURE CITED}

Adams J, Bate GC, O'Callaghan M (1999) Primary producers. In: Allanson BR, Baird D (eds) Estuaries of South Africa. Cambridge University Press, Cambridge, p 91-117

Anandraj A, Perissinotto R, Nozais C, Stretch D (2008) The recovery of microalgal production and biomass in a South African temporarily open/closed estuary, following mouth breaching. Estuar Coast Shelf Sci 79:599-606

Bate GC, Smailes PA (2008) The response of the diatom flora of St Lucia Lake and estuary, South Africa, to a severe drought. Afr J Aquat Sci 33:1-15

Begg GW (1978) The estuaries of Natal, Part 1. Natal town and regional planning report. The Natal Town and Regional Planning Commission, Pietermaritzburg

Benfield MC, Bosschieter JR, Forbes AT (1989) Growth and emigration of Penaeus indicus H. Milne-Edwards (Crustacea: Decapoda: Penaeidae) in the St Lucia Estuary, southern Africa. Fish Bull 88:21-28

Bonilla S, Conde D, Aubriot L, Perez MD (2005) Influence of hydrology on phytoplankton species composition and life strategies in a subtropical coastal lagoon periodically connected with the Atlantic Ocean. Estuaries 28:884-895

Cahoon LB (1999) The role of benthic microalgae in neritic ecosystems. Oceanogr Mar Biol Annu Rev 37:47-86

> Carrasco NK, Perissinotto R, Pillay D (2010) Zooplankton of the St Lucia Estuary during the current drought cycle: a comparison between open- and closed-mouth conditions. Mar Ecol Prog Ser 399:157-171

Cholnoky BJ (1968) Die Diatomeenassoziationen der SantaLucia-Lagune in Natal (Sudafrika). Bot Mar (Suppl) 11: $1-121$

Clarke KR, Warwick RM (1994) Change in marine communities: an approach to statistical analysis and interpretation. Natural Environment Research Council UK, Plymouth

Cloern JE (1996) Phytoplankton bloom dynamics in coastal ecosystems: a review with some general lessons from sustained investigation of San Francisco Bay, California. Rev Geophys 34:127-168

Crossland CJ, Kremer HH, Lindeboom HJ, Marshall Crossland JI, Le Tissier MDA (2005) Coastal fluxes in the Anthropocene. The IGBP Series, Springer, Heidelberg

Cyrus DP, Vivier L (2006) Status of the estuarine fish fauna in the St Lucia estuarine system, South Africa, after 30 months of mouth closure. Afr J Aquat Sci 31:71-81
Day JH (1981) Summaries of current knowledge of 43 estuaries in southern Africa. In: Day JH (ed) Estuarine ecology with particular reference to southern Africa. AA Balkema, Cape Town, p 251-329

Fielding PJ, Forbes AT, Demetriades NT (1991) Chlorophyll concentrations and suspended particulate loads in St. Lucia, a turbid estuary on the east coast of South Africa. S Afr J Mar Sci 11:491-498

Fisher TR, Peele ER, Ammerman JW, Harding LW (1992) Nutrient limitation of phytoplankton in Chesapeake Bay. Mar Ecol Prog Ser 82:51-63

Forbes AT, Cyrus DP (1993) Biological effects of salinity gradients reversals in a southeast African estuarine lake. Neth J Aquat Ecol 27:483-488

Forbes AT, Breen CM, Goodman PS, Taylor RH (1987) The Lake St Lucia research programme. In: St Lucia Research Series 1. Natal Parks Board, Pietermaritzburg, p 1-33

Gobler CJ, Cullison LA, Koch F, Harder TM, Krause JW (2005) Influence of freshwater flow, ocean exchange and seasonal cycles on phytoplankton-nutrient dynamics in a temporarily open estuary. Estuar Coast Shelf Sci 65: 275-288

Grindley JR, Heydorn AEF (1970) Red water and associated phenomena in St Lucia. S Afr J Sci 66:210-213

Johnson IM (1976) Studies on the phytoplankton of the St. Lucia system, Paper 9. In: Heydorn AEF (ed) St Lucia Scientific Advisory Council workshop meeting. St Lucia Scientific Advisory Council, Charters Creek, p 13

Kibirige I, Perissinotto R (2003) In situ feeding rates and grazing impact of zooplankton in a South African temporarily open estuary. Mar Biol 142:357-367

Livingston RJ (2001) Eutrophication processes in coastal systems. CRC Press, Boca Raton, FL, p 327

> Lukatelich RJ, McComb AJ (1986) Distribution and abundance of benthic microalgae in a shallow southwestern Australian estuarine system. Mar Ecol Prog Ser 27:287-297

McLusky D, Elliott M (2004) The estuarine ecosystem: ecology, threats and management. Oxford University Press, Oxford, p 214

Millard NAH, Broekhuysen GJ (1970) The ecology of South African estuaries, Part 10. St Lucia: a second report. Zool Afr 5:277-307

Mitchell SF (1989) Primary production in a shallow eutrophic lake dominated alternately by phytoplankton and by submerged macrophytes. Aquat Bot 33:101-110

> Moss B (1994) Brackish and freshwater shallow lakes - different systems or variations on the same theme? Hydrobiologia 276:1-14

Mostert SA (1983) Procedures used in South Africa for the automatic photometric determination of micro-nutrients in seawater. S Afr J Mar Sci 1:189-198

> Nichols FH (1985) Increased benthic grazing — an alternative explanation for low phytoplankton biomass in northern San Francisco bay during the 1976-1977 drought. Estuar Coast Shelf Sci 21:379-388

Nozais C, Perissinotto R, Mundree S (2001) Annual cycle of microalgal biomass in a South African temporarily-open estuary: nutrient versus light limitation. Mar Ecol Prog Ser 223:39-48

Perissinotto R, Nozais C, Kibirige I (2002) Spatio-temporal dynamics of phytoplankton and microphytobenthos in a South African temporarily-open estuary. Estuar Coast Shelf Sci 55:47-58

> Perissinotto R, Nozais C, Kibirige I, Anandraj A (2003) Planktonic food webs and benthic-pelagic coupling in three South African temporarily-open estuaries. Acta Oecol 24: S307-S316 
Perissinotto R, Iyer K, Nozais C (2006) Response of microphytobenthos to flow and trophic variation in two South African temporarily open/closed estuaries. Bot Mar 49:10-22

Pillay D, Perissinotto R (2008) The macrofauna of the St. Lucia Estuary during the 2005 drought year. Estuar Coast Shelf Sci 77:35-46

Pillay D, Perissinotto R (2009) Community structure of epibenthic meiofauna in the St. Lucia estuarine lake (South Africa) during a drought phase. Estuar Coast Shelf Sci 81:94-106

Rodriguez F (1993) The determination and distribution of macrobenthic chlorophyll- $a$ in selected south Cape estuaries. MSc thesis, University of Port Elizabeth, Port Elizabeth

Roy PS, Williams RJ, Jones AR, Yassini I and others (2001) Structure and function of south-east Australian estuaries. Estuar Coast Shelf Sci 53:351-384

Scheffer M (2004) Ecology of shallow lakes. Kluwer Academic, Dordrecht

Schulze RE (2006) Climate change and water resources in southern Africa. Report No. 1430/1/05, Water Research Commission, Pretoria

Sieburth JMcN, Smetacek V, Lenz J (1978) Pelagic ecosystem structure: heterotrophic compartments of the plankton and their relationship to plankton size fractions. Limnol Oceanogr 23:1256-1263

Taylor RH (2006) Ecological responses to changes in the physical environment of the St Lucia Estuary. PhD thesis, Department of Plant and Environmental Sciences, Norwegian University of Life Sciences, Aas

Thomas CM, Perissinotto R, Kibirige I (2005) Phytoplankton biomass and size structure in two South African eutrophic,

Editorial responsibility: Graham Savidge,

Portaferry, UK temporarily open/closed estuaries. Estuar Coast Shelf Sci 65:223-238

Underwood GJC, Kromkamp J (1999) Primary production by phytoplankton and microphytobenthos in estuaries. Adv Ecol Res 29:93-153

van der Berg MS, Coops H, Meijer ML, Scheffer M, Simons J (1998) Clear water associated with a dense Chara vegetation in the shallow and turbid Lake Veluwemeer, The Netherlands. In: Jeppesen E, Søndergaard M, Søndergaard $M$, Christoffersen $K$ (eds) The structuring role of submerged macrophytes in lakes. Springer-Verlag, New York, p 423

van Niekerk L (2004) Preliminary determination of the ecological reserve on a rapid level for the St Lucia Estuary. Resource Directed Measures Office Report, Department of Water Affairs and Forestry, Pretoria

Wallace JH, van der Elst RP (1975) The estuarine fishes of the east coast of South Africa, Part IV. Occurrence of juveniles in estuaries, Part IV. Ecology, estuarine dependence and status. Investigational Report No. 42, Oceanographic Research Institute, Durban

Welschmeyer NA (1994) Fluorometric analysis of chlorophyll $a$ in the presence of chlorophyll $b$ and pheopigments. Limnol Oceanogr 39:1985-1992

Whitfield AK (1998) Biology and ecology of fishes in southern African estuaries. Ichthyological Monographs of the JLB Smith Institute of Ichthyology, No. 2. JLB Smith Institute of Ichthyology, Grahamstown

Zar JH (1999) Biostatistical analysis. Prentice Hall International, Upper Saddle River, NJ

Submitted: October 2, 2009; Accepted: February 13, 2010 Proofs received from author(s): April 23, 2010 